\title{
Morpho-Agronomical Diversity of Forest Clove in Moluccas, Indonesia
}

\author{
Asri Subkhan Mahulette ${ }^{1,2}{ }^{2}$ Hariyadi $^{3 *}$, Sudirman Yahya ${ }^{3}$, Ade Wachjar ${ }^{3}$, Ilyas Marzuki ${ }^{2}$ \\ 'Studi Program of Agronomy and Horticulture, Graduate School, IPB University (Bogor Agricultural University), Bogor, Indonesia \\ ${ }^{2}$ Agrotechnology Study Program, Faculty of Agriculture, Pattimura University, Kampus Unpatti Poka, Ambon, Indonesia \\ ${ }^{3}$ Department of Agronomy and Horticulture, Faculty of Agriculture, IPB University (Bogor Agricultural University), Bogor, Indonesia
}

\section{ARTICLE INFO}

Article history:

Received August 20, 2018

Received in revised form May 22, 2019

Accepted September 30, 2019

\section{KEYWORDS:}

forest clove,

genetic diversity,

morpho-agronomical characters

\begin{abstract}
Forest clove (Zyzygium aromaticum) is a type of wild clove found in Moluccas. The increasing interest of farmers in cultivating this plant leads to complete their information of morpho-agronomical characteristics which could provide diversity reflecting morpho-agronomical their distribution areas. This study aimed to characterize the morpho-agronomical traits of Forest clove plants in Moluccas. By survey, Forest clove more than 15 year old tree totalling of 50 populations were observed their 54 morpho-agronomical characteristics in two areas (Ambon and Seram) from March to June 2018. Two aromatic cloves, namely Tuni and Zanzibar were used for comparative analysis. The results showed that Forest cloves had a similarity of $\mathbf{7 8 \%}$ among the population and grouped into 3 groups with a morpho-agronomical variation of $22 \%$. On the contrary, Forest cloves and comparators (Tuni and Zanzibar) had morpho-agronomical differences of $58 \%$. Based on the main component analysis, there were 11 most influential characters of Forest cloves (leaf size index, leaf length, leaf width, leaf area, petiole length, flower length, diameter of flower tube, ripe flower weight, fruit length, fruit width, and fruit weight) which could be descriptors for this plant species.
\end{abstract}

\section{Introduction}

Cloves belong to the family Myrtaceae and are native plant of Indonesia, in particular the Moluccas Islands being one of their local origin (Hadipoentyanti 1997; Alfian et al. 2019). Most of a clove is produced to meet domestic demands as raw material for cigarettes. Less than $10 \%$ of its production is used for spices, medicinal ingredients, food preservatives, and others (Syukur et al. 2016).

Cloves are an important plantation in Indonesia, particularly as a contributor to national income and state foreign exchange through cigarette excise tax. Cigarette excise tax from clove along with tobacco in 2015 has reached 139.5 trillion rupiah or $95 \%$ of total excise revenue (Ditjenbun 2017). An increasing national production of clove is needed to dealthe developing clove cigarette manufacturers. Most of the national clove production is absorbed by the clove cigarette factory and the supplied shortage is obtained through

\footnotetext{
* Corresponding Author

E-mail Address: hariyadiipb@rocketmail.com
}

the import of cloves. Indonesia's clove export in 2015 amounted to 12,889 tons and decreased to 8,477 tons in 2016 . On the contrary, clove import volume increased from 11 tons in 2015 to 6,571 tons in 2016 (Ditjenbun 2016). This changed condition is as a result of high absorption of clove (93\%) by cigarette manufacturers, in order to meet other industries. As consequence, high efforts should be done to extent its growing area and national production, such as through the utilization of potential germplasm growing area in Indonesia.

High genetic resources of clove was found in Indonesia with species diversity centers in the Moluccas Islands. The inventoried diversity of Indonesian clove germplasm consists of wild, primitive, landrace, and commercial types (Koerniati 1997). Forest clove (Zyzygium aromaticum) belongs to wild cloves which are found in northern and middle Moluccas Islands as well as Irian region (this day known as Papua). This type of clove is characterized by the appearance of large and sturdy tree with low branching on the main stem, and round to oval canopy. In addition, the leaves are larger, wider and thicker, the tip is less sharp than the cultivation type (Koerniati 1997). This wild 
type of clove is different from primitive cloves, such as those found in the Moluccas Islands, namely Afo, Raja, Moya, Tae, Ambon, Siputih, Sikotok, and Zanzibar (Koerniati 1997). Previously, (Pool et al. 1986) had also classified cloves based on 35 morpho-agronomical traits into three major groups, namely cultivation cloves, native Moluccas cloves and wild cloves. Forest clove considerably belongs into groups of wild cloves, in addition to Raja, Amahasu, Haria Gunung, Sibela, and Indari. Four cultivated cloves (Zanzibar, Siputih, Sikotok, and Ambon) are in the same group, whereas native Moluccas cloves are grouped in the same clade including AFO I, AFO II, Tibobo, Tauro, Sibela, Indari, Air Mata, Dokiri, and Daun Buntal.

Forest clove in Moluccas is morpho-agronomically different from commercial cloves such as Tuni and Raja cloves. As a consequence of lacking aroma, Forest and Raja are considered to be non-aromatic cloves, while Tuni cloves are classified into aromatic groups. Clove cultivation in Moluccas is generally dominated by Tuni species, of which Tuni clove from Buru Selatan Regency have just been released as superior variety (Kementan 2013). However studies of Raja clove and Forest cloves are still limited, allowing its low information of morphoagronomical diversity.

Forest clove is characterized by low eugenol levels which affect to its lower price that than sharp scented cloves like Tuni. However, at present the farmers interest to develop Forest clove in Moluccas starts increasing along with the improving price in market. Advantages of Forest clove could be considered such as studier growth, resistant to pests and diseases, continues production every year and less fluctuation, heavier flower weights and a rapid growth.

Forest clove is predominantly cultivated in Moluccas, particularly in Hitulama, Hitumesing, Mamala, and Morella Villages, Maluku Tengah (Middle Moluccas) Regency and Latu and Hualoy Villages in Seram Island, SeramBarat(WestSeram)Regency(Mahuletteetal.2019). However, less study of morpho-agronomical characters Forest clove have been reported. Characterization of morpho-agronomical and important traits is useful for varieties development (Marzuki et al. 2008).

This study aimed to estimate genetic diversity of Forest cloves based on morpho-agronomical characters in Moluccas.

\section{Materials and Methods}

Productive Forest clove of more than 15 year oldtrees belonging to farmers located in plantation areas in Moluccas. This forest clove species has been identified at Bogoriense herbarium, Bogor-Indonesia LIPI-Cibinong Research Center as Zyzygium aromaticum L. Merr and
Perry. Morphological characters was observed in two tree areas of Forest clovein Moluccas, namely Ambon (Hitulama Village) and Seram (Latu Village) in March to June 2018.

The study used survey method and trees to be observed was chosen randomly. Their morphology characters of plant was characterized in the flowering period until the end of reproductive phase including fruits and seeds. As many as 50 tress of Forest clove population were chosen randomly, and 10 samples were taken from each tree to observe the morphology of each individual tree. Fifty four morpho-agronomical characteristics obervation of Forest clove including the overall characteristic of trees, stems, branches, leaves, flowers, fruits, and seeds were observed referred to Pool and Bermawie (1986) and modified Tropical Fruit Descriptors (IPGRI 1980). All collected data were scored and subjected to be analyzed statistically. Hierarchical Cluster Analysis (HCA) and Principle Component Analysis (PCA) were performed using R Stat 3.1.0 software.

\section{Results}

\subsection{Morpho-Characteristics}

The results of the heatmap analysis show that strong characters are marked by increasingly thick colors while weak characters have faded colors (Figure 1). The results of morpho-agronomical characterization of Forest clove showed that the leaves of Forest clove were generally relatively long and wide, oval with dark green to greenish yellow (green group or yellow group) and thicker, leaf venation more prominent, and had less clove-distinctive scents. In addition, the average Forest clove plant has slightly flat leaf edge with leaf tip which is slightly rounded (obtus). In general, Forest clove plant leaves are less flavorful because they belong to non-aromatic cloves. In contrast to the comparison aromatic clove groups namely Tuni and Zanzibar which have smaller and elliptical, thin leaf sizes, with wavy leaf edges and tapered leaf tips, and clove-distinctive scents.

Forest clove plants have round funnel-shaped ripe flowers with the size of the flower length, tube diameter, flower weight and flower stalk weight which is larger than the flower of aromatic types such as Tuni and Zanzibar and has light yellow green color (154D) at the ripe phase and less clove-distinctive scents. Unlike the clove flowers of the aromatic types namely Tuni and Zanzibar, the clove flowers are generally pale greenish colored (2D) and strong pink colored (49A) on Zanzibar cloves when entering the ripe phase and both have strong clove-distinctive scents, due to belong to aromatic cloves type. Harvest time of Forest 


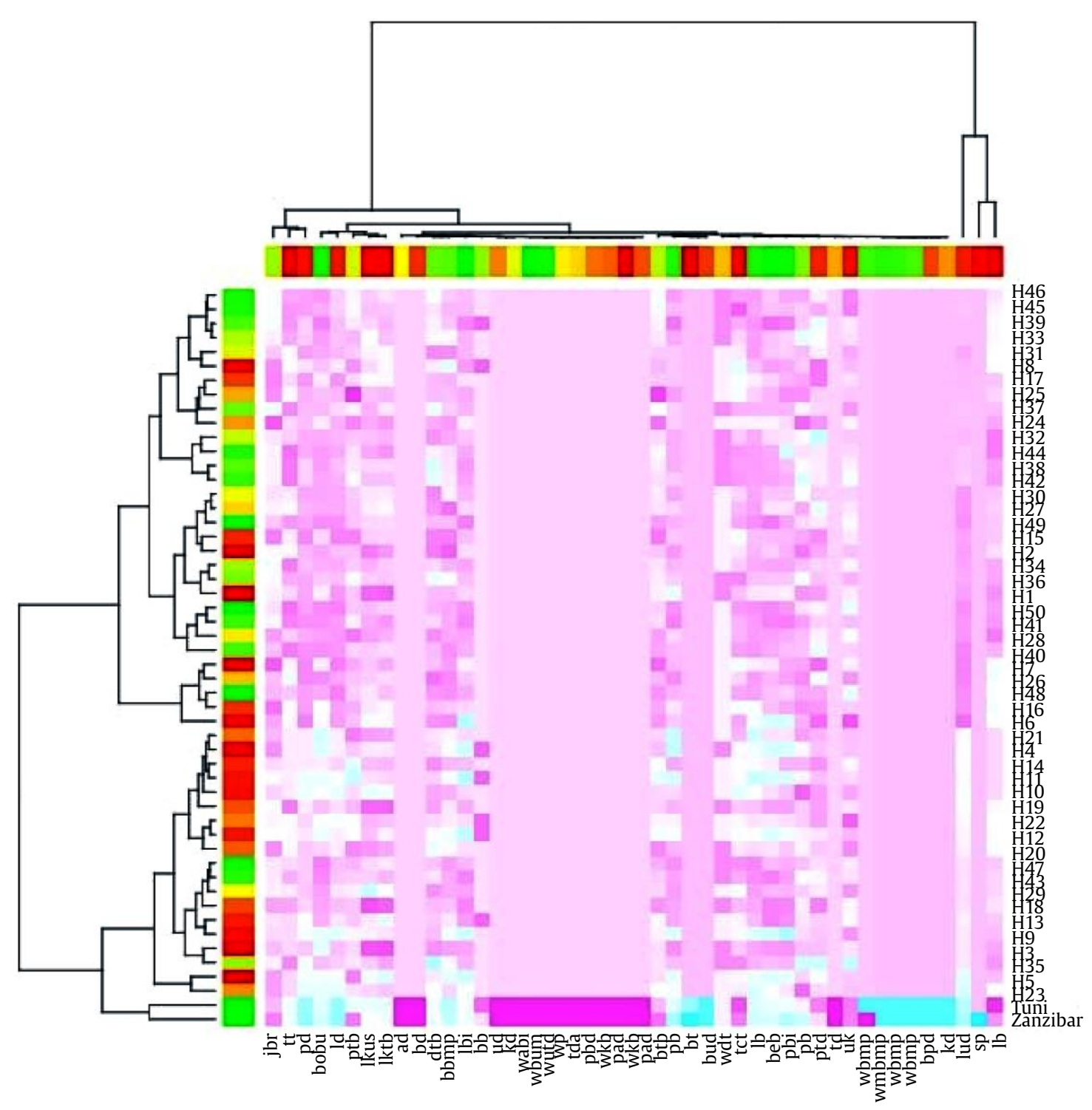

Figure 1. Heatmap of morpho-agronomical characters of Forest cloves

clove in Moluccas generally occurs in March while the aromatic cloves of Tuni and Zanzibar in general being harvested in October. Forest clove flower when blooming is generally light yellow green (154D). While blooming flower of Tuni has deep pink color (52C) and strong red (53D) on Zanzibar.

After entering physiologically mature, Forest clove fruit is generally conical in shape as in the aromatic type of Tuni and Zanzibar. However, the difference with the aromatic types of Tuni and Zanzibar lies in the length, diameter, and weight of the fruit where in general Forest clove has larger length, diameter, and fruit weight and is dark red colored (59A). While the aromatic clove fruits of Tuni and Zanzibar generally have smaller length, diameter and weight compared to Forest cloves and dark purple colored (79A) on Tuni cloves and dark purplish colored (7FA) on Zanzibar cloves after mature physiologically.

Forest clove seeds are conical shaped like seeds on Tuni and Zanzibar aromatic cloves yet have larger length, diameter, and weight and are strong purplish red colored (59D). While the aromatic clove seeds of Tuni and Zanzibar generally have the length, diameter, and weight of seeds which are much smaller than Forest clove seeds and light purple colored (75B). Forest clove seeds are recalcitrant which is same as Tuni and Zanzibar aromatic clove seeds with radicles that have formed at the seeds base.

\subsection{Agronomical Characteristics}

Forest clove group has quite heavy average ripe flower weight ranging from $0.58-0.82 \mathrm{~g}$. The flower 
weight of Forest clove group is averagely larger than Tuni and Zanzibar aromatic clove flower weight which averagely ranged from $0.35 \mathrm{~g}$ for Tuni cloves and $0.38 \mathrm{~g}$ for Zanzibar cloves. Forest clove type has higher water content of $\pm 64.1 \%$ compared to the water content of ripe flower weight of Tuni and Zanzibar clove which are \pm 58.84 and $\pm 59.61 \%$, respectively. One $\mathrm{kg}$ of wet Forest clove flowers shrink to $\pm 313.6 \mathrm{~g}$ of dried flowers.

Forest cloves have an average number of flowers per series ranging from 11.6-15.0 and has larger size and weight than the flowers on Tuni and Zanzibar aromatic cloves. The number of flowers in each series of aromatic cloves of Tuni is about 15 flowers on average, while on Zanzibar there are about 20 flowers per series, but both have smaller size and weight compared to the size and weight of Forest clove flower. Forest clove has lower eugenol flowers level ranging from $\pm 66 \%$. While the eugenol flower levels in the Tuni and Zanzibar aromatic cloves were much larger at $\pm 84 \%$ in Tuni clove and $\pm 76 \%$ in Zanzibar clove.

\subsection{Morpho-agronomical Diversity Among Forest Clove Populations}

Characterization 50 Forest cloves population in Moluccas using HCA produced dendrogram showing the morpho-agronomical diversity among the population (Figure 2). Based on the results of the Hierarchical Cluster Analysis (HCA), it shows that Forest clove has similarity of more than $78 \%$ among the population and has difference of $58 \%$ with the comparators of aromatic type cloves, which are Tuni and Zanzibar. These results showed that the Forest clove group in Moluccas has a closer kinship than the comparators.

The results of the analysis showed that among the Forest clove population itself there was a morphological variation of $22 \%$, thus the analysis results divided

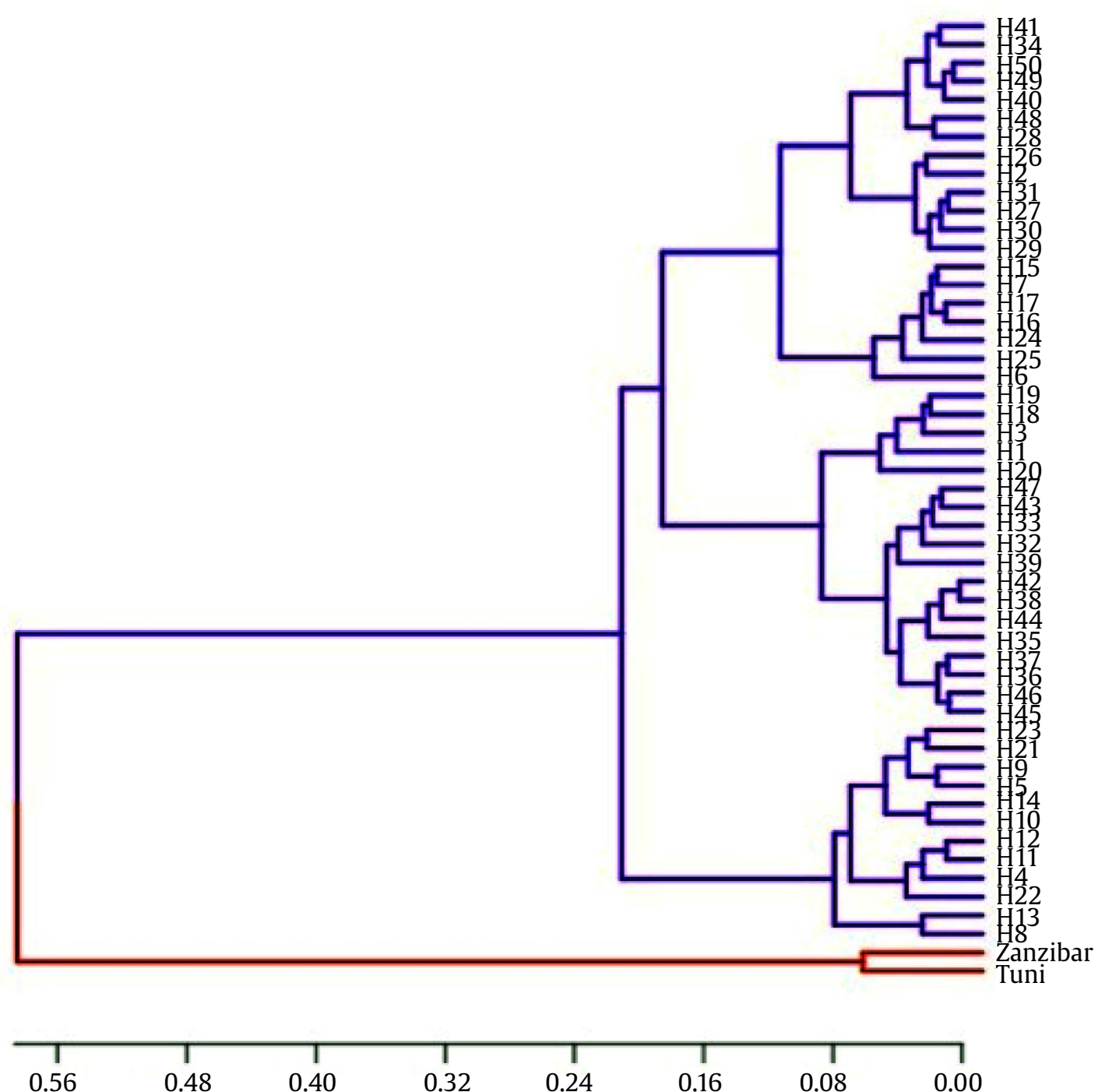

Figure 2. Dendrogram clustering of 50 Forest clove populations in Moluccas based on morpho-agronomical characters 
Forest clove into 3 groups. First group consists of 20 accessions which grouped with $88 \%$ similarity. This group is characterized by the morphology of leaves, flowers, fruits, and seeds which are the largest among entire Forest clove population. The second group of Forest clove population consists of 18 accessions with $90 \%$ similarity level. Members of this group's population have medium sized leaf, flower, fruit, and seed. The last group of Forest clove population consists of 12 accessions with similarity level of $92 \%$. The most prominent characteristics of the members of this group population are the smallest size of leaves, flowers, fruit, and seeds among entire Forest clove population.

Forced direct graph (Figure 3) illustrates the closeness of the relationship among the species of Forest cloves. The results of the analysis showed that individual Forest clove plants of H2, H26, H27, H29, H30, $\mathrm{H} 31, \mathrm{H} 48$ had a close relationship based on similarities in morphological characters so that they were grouped in group I, whereas individual Forest clove plants H37, H42, $\mathrm{H} 45, \mathrm{H} 47$ also had closeness relationship and belonged to group II. Likewise, individual plants of H4, H5, H9, $\mathrm{H} 10, \mathrm{H} 11, \mathrm{H} 12, \mathrm{H} 21, \mathrm{H} 22$ had a close relationship based on the similarity of characters possessed and belonged to group III in the grouping of Forest cloves.

\subsection{Principle Component Analysis (PCA)}

PCA was used to classify individual Forest clove based on similarities among variables. Based on the results of the PCA, there were 11 main characteristics

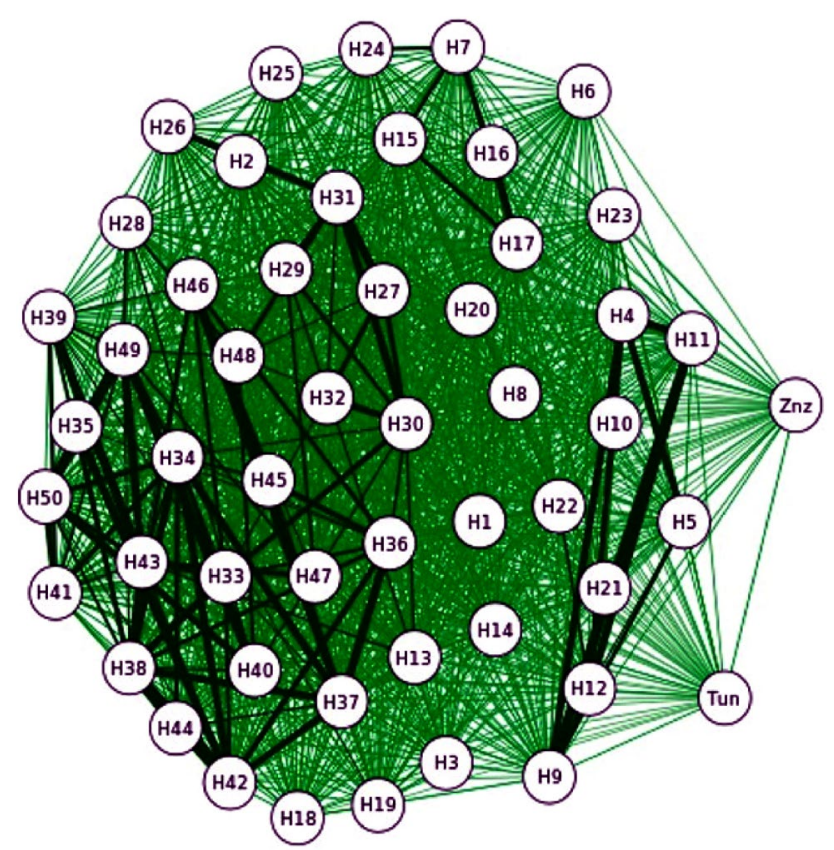

Figure 3. Forced direct graph of 50 Forest clove populations based on morpho-agronomical characters. H1-50 = Forest cloves, $\mathrm{Znz}=$ Zanzibar cloves, Tun = Tuni cloves that most affected the Forest clove population, namely leaf size (index), leaf length, leaf width, leaf area, petiole length, flower length, flower tube diameter and ripe flower weight, fruit length, fruit width, fruit weight (Figure 4). While the comparators from aromatic cloves, namely Tuni and Zanzibar, had not shown strongness on any characteristics.

Based on PCA, the results showed that the strong characters in fruit weight and fruit width were shown in individual Forest clove plants of H34, H46, H47, $\mathrm{H} 49$ while the strong characters in fruit length were shown in individual Forest clove plants of H3, H41, H50. Strong characteristics in leaf length, leaf width, and leaf area of Forest clove populations were also shown by Forest clove individuals of H25, H29, H30 while strong characters in leaf stalk length were shown in Forest clove individuals of $\mathrm{H} 14$ and H45. The strong character of leaf size (index) was shown in individuals of $\mathrm{H} 9$ and $\mathrm{H} 10$. The strong character of the flower length was also shown by individual Forest cloves of $\mathrm{H} 1, \mathrm{H} 2$, H17. While the character of flower tube diameter was shown Forest clove individuals of H7, H15, H24, H26. Furthermore, the strong character of ripe flower weight was shown by Forest clove individual of H48.

\section{Discussion}

Study of Forest clove morphology with comparison of aromatic cloves, namely Tuni and Zanzibar, shows grouping pattern. The difference based on the heatmap

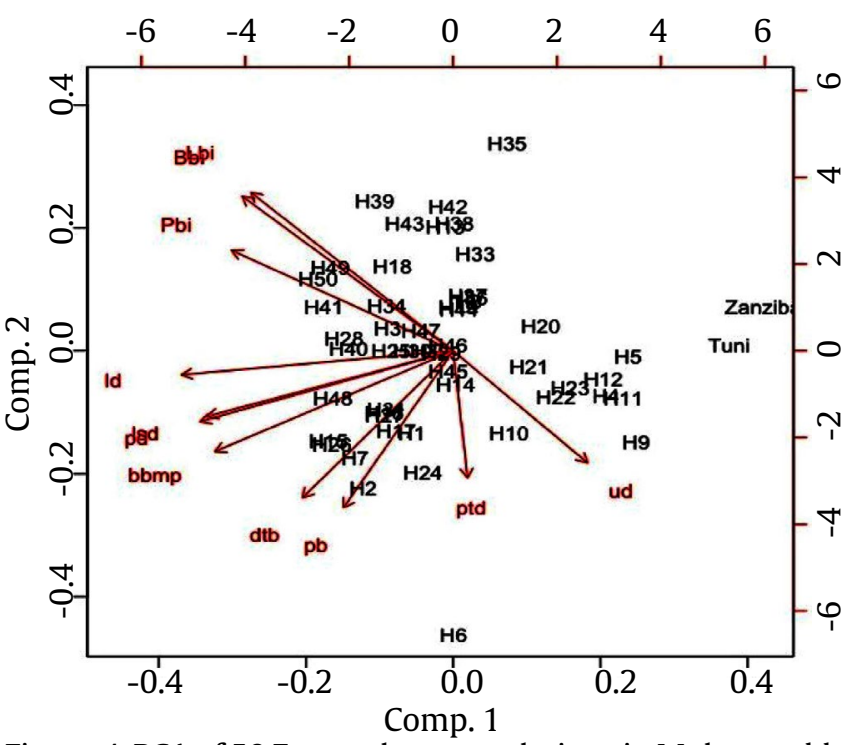

Figure 4. PCA of 50 Forest clove populations in Moluccas. bb = fruit weight, $\mathrm{lb}=$ fruit width, $\mathrm{pb}=$ flower length, $\mathrm{ld}$ = leaf width, lsd = leaf area, pd = leaf length, bbmp $=$ ripe flower weight, $\mathrm{dtb}=$ flower tube diameter, $\mathrm{pb}=$ fruit length, ptd = leaf length, ud = leaf size (index) 
for Forest clove group and the comparison of Tuni and Zanzibar is illustrated in the characters of leaves, flowers, fruits, and seeds. Forest clove shows strong morpho-agronomical characteristics in traits such as flower length, tube diameter, flower weight, seed length, seed width, seed weight, and fruit width. While the strong character in the comparison of Tuni and Zanzibar lies in the color of shoots, leaf edge, shape of leaf tip, color of ripe flower, and leaves aroma. Morphocharacteristics information of Forest clove required as a first step Forests clove commodity development in the future. It is required for the release of the new variety (Syukur et al. 2016), and give a database for cloves in a region (Suparman et al. 2018).

Based on agronomical characteristic, Forest clove plants have higher ripe flower weight compared to ripe flower weight of Tuni and Zanzibar aromatic cloves. The larger ripe flower weight of Forest clove group is caused by Forest clove type has higher water content compared to the water content of ripe flower weight of Tuni and Zanzibar. High flower water content causes Forest clove to experience greater weight loss than the weight loss on the aromatic cloves of Tuni and Zanzibar when being dried. Although it has larger weight of ripe flowers, Forest clove has lower eugenol flowers level. Harvesting of Forest clove in Moluccas occurred in early March while aromatic types like Tuni and Zanzibar cloves occurred in October. These different harvest times cause clove farmers in Moluccas, particularly in their distribution areas, to remain interested in cultivating Forest clove because they can earn income from Forest cloverest when aromatic type cloves which are Tuni and Zanzibar have not yet produced.

Morpho-agronomical diversity among Forest clove populations, shown by cluster analysis. Cluster analysis is used to classify the Forest clove population previously unclassified. The results of cluster analysis can use to identify the morpho-agronomical characters and important yield components and use for breeding studies (Ahmadizadeh and Felenji 2011). Cluster analysis can also be used to evaluate the diversity of plants for the purpose of selecting high yielding plant genotypes (Wang et al. 2014). Based on the results of the Hierarchical Cluster Analysis (HCA), the Forest clove group in Moluccas has a closer kinship than the comparators. Accession which has much in common is accession have a closer relationship, whereas accession has many differences is that having a more distant kinship (Jan et al. 2012).
The grouping of Forest cloves in Moluccas informs that among the population there Forests clove variants even with a small percentage. Variants that appear are caused by various factors such as genetics and the environment and the interaction of both. Information on the diversity of genetic traits and levels of variability will help in selecting superior genotypes (Singh et al. 2013).

Forced direct graph shows that species of Forest cloves with more common characteristics will have a closer relationship. The accession of plants can be grouped into the same group if they have more similarities in variables or similarities in characteristics (Maji and Shaibu 2012). The relationship among the species of Forest cloves based on morpho-agronomical characterization is important to study the development of Forest clove. Morpho-agronomical characterization of germplasm accessions can provide information in the development of breeding. The high variability among plant accessions is also important for the study of plant species genetics (do Nascimento et al. 2011).

Based on the results of the PCA, there were main characteristics that most affected the Forest clove population, namely leaf size (index), leaf length, leaf width, leaf area, petiole length, flower length, flower tube diameter and ripe flower weight, fruit length, fruit width, fruit weight. Analysis of the specific character of the Forest cloves is importantly used for plant selection. The selection of superior ancestor in nurseries using PCA can help plants group based on the characteristics that most contribute to the genotype groups. Furthermore, morpho-agronomical characters used are also important, especially in plant breeding as it relates to the collection and evaluation of genotypes so that they are not extinct (Ahmadizadeh and Felenji 2011).

The main component analysis is able to test variations by estimating the characters that most contributed to the total variation of the characters analyzed (Yugandhar et al. 2018). PCA is used to characterize plants with high variability so that it is widely used to group agronomic variations in many plant genotypes (Afuape et al. 2011). PCA has been widely used to study morpho-agronomical variations in plants such as potatoes (Ahmadizadeh and Felenji 2011), sweetpotato (Afuape et al. 2011), bread wheat (Habibpour et al. 2012), rice (do Nascimento et al. 2011; Yugandhar et al. 2018), garlic (Wang et al. 2014; Albuquerque et al. 2017; Sharma et al. 2018). The 
morpho-agronomical characters that most influences are determined based on the total eigenvalue (Mattjik and Sumertajaya 2011). The main component analysis is able to analyze the main components independent of all plant characteristics analyzed separately (Sharma et al. 2018).

We conclude that forest clove in Moluccas has a similarity of $78 \%$ among its population and has difference of $58 \%$ with aromatic type cloves of Tuni and Zanzibar. Forest clove in its distribution area in Moluccas is divided into 3 groups with morpho-agronomical variations of $22 \%$. There are 11 main characters that are most influential on Forest clove population, namely leaf size (index), leaf length, leaf width, leaf area, petiole length, flower length, tube diameter and ripe flower weight, length of fruit, width of fruit, fruit weight.

\section{Acknowledgements}

The authors are grateful to the Indonesian Endowment Fund for Education (LPDP) 2016, Ministry of Finance, Indonesia for their financial support.

\section{References}

Afuape SO et al. 2011. Multivariate assessment of the agromorphological variability and yield components among sweetpotato (Ipomoea batatas (L.) Lam.) landraces. African J Plant Sci 5:123-132.

Ahmadizadeh M, Felenji H. 2011. Evaluating diversity among potato cultivars using agro-morphological and yield components in fall cultivation of jiroft area. AmericanEurasian J Agric Environ Sci 11:655-662.

Albuquerque J de R de A et al. 2017. Agromorphological performance of garlic landraces in Piauí, Brazil. Ciência Rural St Maria 47:4-9.

Alfian A et al. 2019. Morphological character of raja clove (Syzygium aromaticum L. Merr and Perry .) native from Ambon Island. In: Proceedings of The $1^{\text {st }}$ International Conference of Interdisciplinary Research on Green Environmental Approach for Sustainable Development (ICROEST), Vol. 343. Makassar: IOP Conference Series: Earth and Environmental Science. pp. 1-4. DOI:10.1088/1755-1315/343/1/012150

Ditjenbun. 2016. Statistik Perkebunan Indonesia Komoditas Cengkih 2015-2017. Jakarta: Kementerian Pertanian.

Ditjenbun. 2017. Rencana Strategis (RENSTRA) Direktorat Jenderal Perkebunan Tahun 2015-2019 (edisi revisi ke-2). Jakarta: Kementerian Pertanian.

Habibpour M et al. 2012. Assessment relationship between agro-morphological traits and grain yield in bread wheat genotypes under drought stress condition. African J Biotechnol 11:8698-8704. DOI:10.5897/AJB11.3421
Hadipoentyanti E. 1997. Tipe dan karakteristik cengkih. In: Kemala S, Hasanah M, Djisbar A, Asman A, Nurjaannah N (Eds.). Monograf Tanaman Cengkih No. 2. Bogor: Balittro. pp. 17-24.

[IPGRI] International Plant Genetic Resources Institute. 1980. Tropical Fruit Descriptor. Thailand: IPGRI-Southeast Asia Regional Committee.

Jan HU et al. 2012. Estimation of genetic variability in turmeric (Curcuma longa L.) germplasm using agro-morphological traits. Pak J Bot 44:231-238.

Kementan. 2013. SK Kementan Nomor 4964/Kpts/ SR.120/12/2013. Tentang Pelepasan Cengkih Tuni Bursel, Sebagai Varietas Unggul. Jakarta.

Koerniati S. 1997. Keanekaragaman plasma nutfah cengkih dan pelestariannya. In: Kemala S, Hasanah M, Djisbar A, Asman A, Nurjaannah N (Eds.). Monograf Tanaman Cengkih No. 2. Bogor: Balittro. pp. 25-32.

Mahulette AS et al. 2019. The physicochemical components and characteristic from essential oils of forest cloves Syzygium aromaticum (Myrtaceae) in Maluku Province, Indonesia. Plant Archives 192:466-472.

Maji AT, Shaibu AA. 2012. Application of principal component analysis for rice germplasm characterization and evaluation. J Plant Breed Crop Sci 4:87-93. DOI:10.5897| JPBCS11.093

Marzuki I et al. 2008. Karakterisasi morfoekotipe dan proksimat pala Banda (Myristica fragrans Houtt). Bul Agron 36:145-151.

Mattjik A, Sumertajaya I. 2011. Analysis of Mutiple Variables Using SAS. Bogor: Departement of Statistics IPB.

do Nascimento WF et al. 2011. Agro-morphological characterization of upland rice accessions. Sci Agric (Piracicaba, Braz.) 68:652-660.

Pool P, Bermawie N. 1986. Kriteria Seleksi Pohon Induk Cengkih. Bogor: Balittro.

Pool P et al. 1986. Variation in clove (Syzygium aromaticum) germplasm in the Muluccan Islands. Euphytica 35:149-159.

Sharma VR et al. 2018. Morphological classification of genetic diversity of garlic (Allium sativum L.) germplasm for bulb and yield-related traits using principal component analysis. Int J Curr Microbiol Appl Sci 7:2016-2022.

Singh RK et al. 2013. Intra and inter cluster studies for quantitative traits in garlic (Allium sativum L.). SAARC J Agri 11:61-67.

Suparman et al. 2018. Diversity and mapping clove varieties (Syzygium aromaticum) on Hiri Island, in Ternate Municipality. IOSR-JAVS 11:11-16. DOI:10.9790/23801108011116

Syukur C et al. 2016. Clustering of progeny clove a ccessions from cimanggu population in sumedang based on the morphologycal characters. J Littri 22:29-36.

Wang $\mathrm{H}$ et al. 2014. Diversity evaluation of morphological traits and allicin content in garlic (Allium sativum L.) from China. Euphytica 198:243-254. DOI:10.1007| s10681-014-1097-1

Yugandhar R et al. 2018. Principal component analysis for agromorphological and quality characters in germplasm of rice (Oryza sativa L.). IJABR 8:268-273. 